\title{
Determining factors of financial performance of agricultural listed companies in China
}

Reception of originals: $08 / 24 / 2020$

Release for publication: 02/07/2021

\author{
Lujing Liu \\ Associate Professor in School of Management \\ Institution: School of Management, Qingdao Agricultural University \\ Address: No. 700 Changcheng Road, Chengyang District, 266109, Qingdao, China \\ E-mail: liulujing@qau.edu.cn \\ Jian Xu \\ $\mathrm{PhD}$ in Accounting \\ Institution: School of Management, Qingdao Agricultural University \\ Address: No. 700 Changcheng Road, Chengyang District, 266109, Qingdao, China \\ E-mail: xujiansword@163.com \\ (Corresponding author) \\ Yue Shang \\ Lecturer, Business College \\ Institution: Business College, Yantai Nanshan University \\ Address: No. 12 Daxue Road, Donghai Tourism Resort, 265713, Yantai, China \\ E-mail: shangyue59@163.com
}

\begin{abstract}
This paper aims to analyze the determinants of financial performance of agricultural listed companies in China. Multiple regression approach is applied based on the sample of 39 agricultural listed companies during the six-year period (2013-2018). Financial performance is measured by return on sales (ROS), return on assets (ROA), and return on equity (ROE). Internal factors include firm size, current ratio, debt ratio, long-term liability ratio, sales growth rate, capital intensity, research and development (R\&D) intensity, export intensity, and ownership, and external factors include gross domestic product (GDP) growth rate and consumer price index (CPI) growth rate. The results show that financial performance of China's agricultural listed companies is positively related to firm size, long-term liability ratio, and sales growth rate and negatively related to debt ratio, capital intensity, and export intensity. In addition, external factors have no significant impact on financial performance. This paper may provide useful information for managers as well as policymakers to improve financial performance and achieve corporate sustainable development.
\end{abstract}

Keywords: Determining factors. Financial performance. Agricultural listed companies.

\section{Introduction}

Agricultural sector has its own specificities due to high dependency on natural factors (Arisoy et al., 2017; Fiala et al., 2020). China is a country with the vast majority of rural population, and agriculture has a unique strategic position. It plays an essential role in China's 
national economy (Li et al., 2017; Wagan et al., 2018; Xu and Wang, 2019). According to China's National Bureau of Statistics, in 2018, the total output value of agriculture was 6145.26 billion yuan, and the proportion of added value of agriculture occupied $7.04 \%$ of total gross domestic product (GDP).

Agricultural listed companies have the leading role in the development of China's agricultural modernization (Bugu and Yucheng, 2018). In recent years, these companies face a series of problems such as poor market performance and polarization trend in operation performance (Luo and Zhang, 2012), which attracts little concern of investors (Arisoy et al., 2017).

Sustainable financial performance is the key factor in the success of any organization (Wei et al., 2017). Corporate managers should continuously monitor and analyze performance indicators to prevent business failure. Compared with other industries, financial performance of agricultural listed companies is below the average (Huo, 2016). What's more, firm's financial performance is highly influenced by internal and external variables (Avdalović, 2018).

Understanding the determinants of financial performance is arguably one of the most fertile fields of analysis both for industrial economists and strategic management researchers (Pratheepan, 2014). Every sector does not have the same determinants due to their different operations and characteristics (Pathirawasam, 2011; Bayaraa, 2017). Therefore, in order to achieve long-term development, management of agricultural listed companies has to investigate which factors have a significant impact on financial performance.

The aim of this paper is to examine financial performance determinants of China's agricultural listed companies. This paper is restricted to the relationship among return on sales (ROS), return on assets (ROA), and return on equity (ROE) with the internal and external factors as determinants over the period of 2013-2018.

This paper contributes to the existing literature in the following aspects. First, among most used factors, we analyze the impact of export and external factors on financial performance that is attached less consideration in empirical studies. Second, most studies have focused on developed western countries, and little has been done in emerging countries like China. Finally, the findings will help managers make reasonable decisions to improve financial performance, and provide some guidelines for policymakers to understand how to improve these companies' performance using firm-specific factors.

The structure of this paper is as follows. Section 2 presents the literature review, and Section 3 focuses on the research methodology. Section 4 is empirical results, and Section 5 
presents the conclusion and suggestions.

\section{Literature Review}

Many researchers have examined which variables can determine the firms' financial performance and obtained different results due to the difference in characteristics of samples selected.

An early study conducted by Chowdhury and Amin (2007) showed that working capital has a significant impact on financial management of pharmaceutical firms operating in Bangladesh. Kuntluru et al. (2008) analyzed financial performance of Indian companies and found a positive relationship between firm size and growth and profitability as well as a negative relationship between debt ratio and profitability. Chandrapala and Guneratne (2012) also found similar results. Taking 961 large Australian firms as the sample, Stierwald (2010) pointed out that lagged profit and firm's size have the largest contribution to performance improvement. Pathirawasam (2011) suggested that internal factors (firm size, quick ratio, inventory, and debt ratio) influence financial performance of listed companies by ROA. Azhagaiah and Deepa (2012) argued that volatility and growth in total assets are the major profitability determinants for small firms while growth is important for medium firms in Indian food industry. The findings of Pratheepan (2014) revealed that size positively affects the profitability of Sri Lankan manufacturing companies whereas leverage and liquidity have an insignificant impact.

Recently, Antoun et al. (2018) investigated the determinants of financial performance of banks in central and eastern Europe, finding that size, business mix, bank concentration, economic growth, and inflation rate determines financial performance measured with a performance index. In China's agricultural sector, there is a positive relationship between the degree of equity concentration and agricultural modernization and ROA and a negative relationship between debt ratio and ROA (Bugu and Yucheng, 2018). Jelena et al. (2018), based on the data of medium and large agricultural companies in Serbia, documented that current liquidity, market share, sales revenue growth, insurance, and export have a positive impact on ROA. Dakić et al. (2019) explored the determinants of business success of Serbian food processing companies. The results showed that company size, debt ratio, quick ratio, sales growth, and capital turnover ratio can affect firm profitability (measured by ROA). Vieira et al. (2019) analyzed the determinants of Portuguese firms' performance. They achieved the results that determinants are liquidity, public debt, and insider ownership when 
ROA is used to measure financial performance. According to Xuan (2020), seven main factors can improves business performance of Vietnam technology and manufacturing enterprises, including solvency, firm size, sales growth rate, administrative procedures, access to credit institutions, labor qualifications, and firm age.

\section{Research Methodology}

\subsection{Sample selection}

The sample comprises agricultural companies listed on the Shanghai and Shenzhen stock exchanges over a six-year period (2013-2018). After screening and removing companies with missing variables, companies issuing other kinds of shares, and special treatment (ST) companies, 39 listed companies with 214 observations are left for estimation. Data are taken from the China Stock Market \& Accounting Research (CSMAR) database and the Wind database.

\subsection{Variables}

We measure financial performance, the dependent variable, by using ROS, ROA, and ROE, which has been used in previous research (e.g. Hult et al., 2008; Mijić et al., 2014; Bayaraa, 2017; Kumari and Kumar, 2018; Fiala et al., 2020).

Firm size manifests capability from the aspect of production volume. Chhibber and Majumder (1999), Gschwandtner (2005), Kuntluru et al. (2008), Pathirawasam (2011), Pratheepan (2014), and $\mathrm{Vu}$ et al. (2019) argued that size has a positive impact on financial performance.

Current ratio measures the ability of the firm to meet its short-term obligations. A positive correlation has been found between current asset management and financial performance (Chowdhury and Amin, 2007; Jelena et al., 2018).

There should be an appropriate capital structure that maximizes profit for the organization, as more debt leads to worse financial performance (Chhibber and Majumder, 1999; Kuntluru et al., 2008; Pathirawasam, 2011; Bugu and Yucheng, 2018; Jelena et al., 2018; Dakić et al., 2019). In addition, if a company uses borrowed money for investment, it will bring future economic inflows (Jelena et al., 2018).

Sales growth shows the company's ability to achieve a higher level of revenue in the current period compared to previous period. Jelena et al. (2018), Dakić et al. (2019), and 
Singh et al. (2019) found a positive correlation between sales growth and firm performance.

Capital intensity explains the amount of capital needed per unit of revenue. Harris (1988, 1994) provides evidence for a positive impact of capital intensity on performance. However, Singh et al. (2019) concluded that capital intensity has a negative impact on financial performance of U.S. agricultural cooperatives.

A positive relationship between research and development (R\&D) investment and financial performance has been documented by several studies, such as Falk (2012), Zhu et al. (2017), Xu and Sim (2018), and Chen and Wu (2020).

Export intensity reflects international competitive structure of a firm (Sophia and Gayathri, 2018). Jelena et al. (2018) proved a positive relationship between export and the performance of agricultural companies.

In terms of ownership, stated-owned and private-owned firms coexist in the Chinese mixed market (Jin et al., 2018). Chhibber and Majumder (1999) confirmed that different categories of ownership have varying influences on ROA. The findings of Wei and Tang (2019) revealed that private-owned firms outperform state-owned firms in manufacturing sector.

In addition, GDP growth rate and consumer price index (CPI) growth rate are included to control external influences. Our sample period (2013-2018) is characterized by economic transformation from high-speed growth to high-quality development. According to the World Bank, GDP growth rate in 2013 was 7.8 percent, and it dropped to 6.6 percent in 2018. Gan et al. (2006) and Kosmidou (2008) found a positive relationship between GDP and performance. Antoun et al. (2018) believed that CPI inflation rate has a significant positive impact on asset quality and earnings.

Table 1 lists the variable definition in this study.

Table 1: Variable definition

\begin{tabular}{c|c|c|c}
\hline Variables & Notation & Measurement & $\begin{array}{c}\text { Predicted } \\
\text { sign }\end{array}$ \\
\hline Return on sales & ROS & Earnings before interest and taxes/Net sales & \\
\hline Return on assets & ROA & Net income/Average total assets & \\
\hline Return on equity & ROE & Net income/Average shareholder equity & \\
\hline Firm size & SIZE & Natural logarithm of total assets & + \\
\hline Current ratio & CR & Current assets/Current liabilities & + \\
\hline Debt ratio & LEV & Total liabilities/Total assets & - \\
\hline $\begin{array}{c}\text { Long-term } \\
\text { liability ratio }\end{array}$ & LONG & Long-term liabilities/Total assets & + \\
\hline Sales growth rate & SALES & (Current year's sales - Last year's sales) -1 & + \\
\hline
\end{tabular}

Custos e @gronegócio on line - v. 16, n. 4, Oct/Dec. - 2020. 
Liu, L.; Xu, J.; Shang, Y.

\begin{tabular}{c|c|c|c}
\hline Capital intensity & CAP & Total assets/Total sales & $+/-$ \\
\hline R\&D intensity & RD & R\&D expenditure/Total sales & + \\
\hline Export intensity & EXP & Export sales/Total sales & + \\
\hline $\begin{array}{c}\text { Company } \\
\text { ownership }\end{array}$ & OWN & $\begin{array}{c}\text { Dummy variable that takes 1 if a company is } \\
\text { state-owned, 0 otherwise }\end{array}$ & $+/-$ \\
\hline GDP growth rate & GDP & Growth rate in GDP & + \\
\hline CPI growth rate & CPI & Growth rate in CPI & + \\
\hline
\end{tabular}

Source: Author's own illustration

\subsection{Model specification}

Ordinary least square (OLS) regressions are used for the purpose of analysis. Models (1)-(3) are used to examine financial performance determinants of China's agricultural listed companies in the current study.

$$
\begin{aligned}
& R O S_{i, t}=\beta_{0}+\beta_{1} \operatorname{SIZE}_{i, t}+\beta_{2} C R_{i, t}+\beta_{3} L E V_{i, t}+\beta_{4} L O N G_{i, t}+\beta_{5} S A L E S_{i, t}+\beta_{6} C A P_{i, t}+\beta_{7} R D_{i, t}+\beta_{8} \operatorname{EXP}_{i, t}+\beta_{9} O W N_{i, t}+\beta_{10} \operatorname{CDP}_{i, t}+\beta_{11} C P I_{i, t}+\varepsilon_{i, t} \\
& R O A_{i, t}=\beta_{0}+\beta_{1} S I Z E_{i, t}+\beta_{2} C R_{i, t}+\beta_{3} L E V_{i, t}+\beta_{4} L O N G_{i, t}+\beta_{5} S A L E S_{i, t}+\beta_{6} C A P_{i, t}+\beta_{7} R D_{i, t}+\beta_{8} E X P_{i, t}+\beta_{9} O W N_{i, t}+\beta_{10} G D P_{i, t}+\beta_{11} C P I_{i, t}+\varepsilon_{i, t} \\
& R O E_{i, t}=\beta_{0}+\beta_{1} S I Z E_{i, t}+\beta_{2} C R_{i, t}+\beta_{3} L E V_{i, t}+\beta_{4} L O N G_{i, t}+\beta_{5} S A L E S_{i, t}+\beta_{6} C A P_{i, t}+\beta_{7} R D_{i, t}+\beta_{8} E X P_{i, t}+\beta_{9} O W N_{i, t}+\beta_{10} G D P_{i, t}+\beta_{11} C P I_{i, t}+\varepsilon_{i, t}
\end{aligned}
$$

where $i=1, \ldots n$ and $t=1, \ldots t$ represent firm and year, respectively; $\beta$ is the presumed parameter; $\varepsilon$ denotes the disturbance.

\section{Empirical Results}

\subsection{Descriptive statistics}

Table 2 shows descriptive statistics of all variables. The mean value of ROS, ROA, and ROE is $-0.0222,0.0086$, and -0.0190 , respectively, which means that selected agricultural listed companies in China have relatively lower financial performance. The standard deviation of ROS is 1.2700 , which shows that these companies vary greatly by their ROS. The mean value of $\mathrm{CR}$ is 2.5474 , which implies that agricultural listed companies are liquid in observed period. LEV has a mean value of 0.4223 , which suggests that the debt level of these companies is relatively high. The mean LONG of 0.0460 suggests that agricultural listed companies have a low degree of risk. The mean value of SALES is 0.1031 , indicating $10 \%$ average annual growth in the revenue of the selected companies. For CAP, the mean value is 2.8117, suggesting that agricultural listed companies are generating positive revenues on their assets. The mean RD (0.0191) suggests that investment in R\&D is at a very low level in agricultural sector. In addition, the mean value of EXP is 0.1054 . In this study, about 45 
percent of our selected sample consists of state-owned agricultural companies.

Table 2: Descriptive statistics

\begin{tabular}{c|c|c|c|c|c|c}
\hline Variables & $\mathrm{N}$ & Mean & Median & Max & Min & S.D. \\
\hline ROS & 214 & -0.0222 & 0.0718 & 0.5894 & -18.2904 & 1.2700 \\
\hline ROA & 214 & 0.0086 & 0.0187 & 0.3300 & -1.8591 & 0.1522 \\
\hline ROE & 214 & -0.0190 & 0.0351 & 0.6236 & -6.8500 & 0.5051 \\
\hline SIZE & 214 & 21.8121 & 21.6943 & 24.7113 & 19.4777 & 0.9465 \\
\hline CR & 214 & 2.5474 & 1.5783 & 28.1765 & 0.1739 & 3.6086 \\
\hline LEV & 214 & 0.4223 & 0.4041 & 0.8978 & 0.0496 & 0.1888 \\
\hline LONG & 214 & 0.0460 & 0.0132 & 0.4170 & 0 & 0.0784 \\
\hline SALES & 214 & 0.1031 & 0.0548 & 2.4844 & -0.6192 & 0.3785 \\
\hline CAP & 214 & 2.8117 & 2.2005 & 13.3335 & 0.6981 & 1.9968 \\
\hline RD & 214 & 0.0191 & 0.0053 & 0.5502 & 0 & 0.0491 \\
\hline EXP & 214 & 0.1054 & 0 & 0.7722 & 0 & 0.1883 \\
\hline OWN & 214 & 0.45 & 0 & 1 & 0 & 0.499 \\
\hline GDP & 214 & 0.070 & 0.069 & 0.078 & 0.066 & 0.0040 \\
\hline CPI & 214 & 0.019 & 0.020 & 0.026 & 0.014 & 0.0037 \\
\hline SOH A A
\end{tabular}

Source: Author's own calculation

Table 3 presents the evolution of financial performance indicators. In 2016, financial performance of agricultural listed companies reached the highest level because of China's supply-side structural reform. The reform aimed to adjust the relationship between supply and demand, optimize resource allocation, and lift the total factor productivity (Gao and Shao, 2018). However, there is a sharp decrease in the three indicators after 2016, and they became less than zero in 2018, reflecting that these companies suffered losses due to excess capacity in the process of replacing old growth drivers with new ones. The three performance indicators have the same trend in the observed period. Figure 1 shows a similar S-shaped curve.

Table 3: Year-wise means for ROS, ROA, and ROE

\begin{tabular}{c|c|c|c}
\hline Year & ROS & ROA & ROE \\
\hline 2013 & 0.0681 & 0.0185 & 0.0212 \\
\hline 2014 & 0.0542 & 0.0121 & 0.0097 \\
\hline 2015 & 0.0262 & -0.011 & -0.0323 \\
\hline 2016 & 0.0775 & 0.0385 & 0.0494 \\
\hline 2017 & 0.0700 & 0.0125 & -0.0046 \\
\hline 2018 & -0.4015 & -0.0187 & -0.1490 \\
\hline Average & -0.0222 & 0.0086 & -0.0190 \\
\hline
\end{tabular}

Source: Author's own calculation 


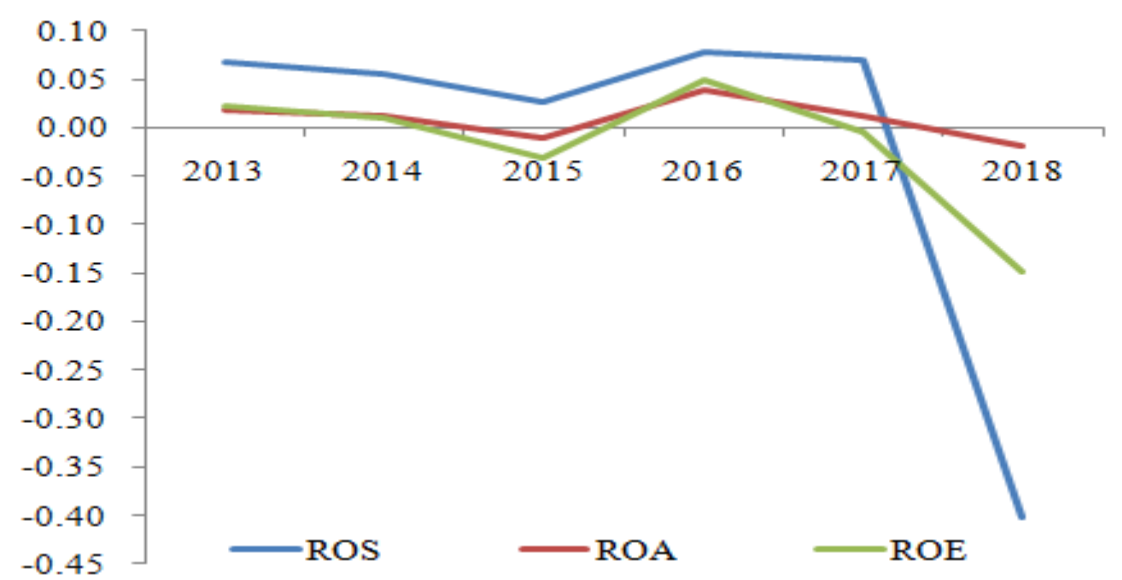

Figure 1: The trend of ROS, ROA, and ROE during 2013-2018

Source: Author's own illustration

Table 4 shows the results of normality tests. The Shapiro-wilk test suggests that all variables do not have the normal data distribution $(p<0.05)$. This implies that further analysis should use Pearson's correlation coefficient analysis.

Table 4: Normality tests

\begin{tabular}{c|c|c|c}
\hline Variable & Statistic & df & Sig. \\
\hline ROS & 0.116 & 214 & 0.000 \\
\hline ROA & 0.432 & 214 & 0.000 \\
\hline ROE & 0.246 & 214 & 0.000 \\
\hline SIZE & 0.984 & 214 & 0.014 \\
\hline CR & 0.474 & 214 & 0.000 \\
\hline LEV & 0.987 & 214 & 0.044 \\
\hline LONG & 0.636 & 214 & 0.000 \\
\hline SALES & 0.859 & 214 & 0.000 \\
\hline CAP & 0.797 & 214 & 0.000 \\
\hline RD & 0.350 & 214 & 0.000 \\
\hline EXP & 0.629 & 214 & 0.000 \\
\hline OWN & 0.633 & 214 & 0.000 \\
\hline GDP & 0.812 & 214 & 0.000 \\
\hline CPI & 0.873 & 214 & 0.000
\end{tabular}

Source: Author's own calculation

\subsection{Correlation analysis}

Table 5 shows the results of correlation analysis. ROS, ROA, and ROE are positively correlated with SIZE and SALES, while these three performance indicators are negatively correlated with LEV and CAP. Variance inflation factors (VIFs) are calculated to be less than 2, which suggests that multi-collinearity is not a major issue (Kennedy, 2003). 
Table 5: Correlation matrix

\begin{tabular}{|c|c|c|c|c|c|c|c|c|c|c|c|c|c|c|}
\hline Variables & 1 & 2 & 3 & 4 & 5 & 6 & 7 & 8 & 9 & 10 & 11 & 12 & 13 & 14 \\
\hline 1 ROS & 1 & & & & & & & & & & & & & \\
\hline $2 \mathrm{ROA}$ & $0.901^{* * * *}$ & 1 & & & & & & & & & & & & \\
\hline $3 \mathrm{ROE}$ & $0.964 * * *$ & $0.965 * * * *$ & 1 & & & & & & & & & & & \\
\hline 4 SIZE & 0.073 & $0.146^{* * *}$ & $0.091^{*}$ & 1 & & & & & & & & & & \\
\hline $5 \mathrm{CR}$ & 0.053 & 0.060 & 0.063 & $-0.429 * * *$ & 1 & & & & & & & & & \\
\hline $6 \mathrm{LEV}$ & $-0.192^{* * * * *}$ & $-0.328 * * * *$ & $-0.294 * * * *$ & $0.259 * * *$ & $-0.538^{* * * * *}$ & 1 & & & & & & & & \\
\hline $7 \mathrm{LONG}$ & 0.077 & -0.019 & -0.006 & $0.099 *$ & -0.058 & $0.410^{* * * *}$ & 1 & & & & & & & \\
\hline 8 SALES & $0.126 * *$ & $0.217^{* * * * *}$ & $0.188^{* * * *}$ & 0.049 & -0.033 & 0.010 & 0.045 & 1 & & & & & & \\
\hline $9 \mathrm{CAP}$ & $-0.323^{* * * *}$ & $-0.355^{* * * * *}$ & $-0.362^{* * * *}$ & $-0.106^{*}$ & $0.257^{* * * * * *}$ & 0.042 & $0.375^{* * * *}$ & $-0.244^{* * * * *}$ & 1 & & & & & \\
\hline $10 \mathrm{RD}$ & 0.003 & 0.005 & 0.014 & -0.064 & 0.069 & $-0.171^{* * * *}$ & $-0.104 *$ & $-0.090^{*}$ & $0.142^{* * *}$ & 1 & & & & \\
\hline 11 EXP & 0.009 & -0.009 & 0.004 & -0.051 & $-0.090^{*}$ & -0.003 & -0.051 & 0.035 & $-0.273 * * * *$ & -0.087 & 1 & & & \\
\hline $12 \mathrm{OWN}$ & 0.059 & -0.013 & 0.034 & $-0.090^{*}$ & $0.141^{* * *}$ & 0.042 & 0.072 & $-0.151^{* * *}$ & -0.016 & $-0.108^{*}$ & $\begin{array}{c}- \\
0.001\end{array}$ & 1 & & \\
\hline $13 \mathrm{GDP}$ & 0.067 & 0.033 & 0.059 & $-0.176^{* * * * *}$ & 0.014 & -0.010 & -0.047 & -0.083 & $-0.113^{* * *}$ & 0.082 & 0.041 & 0.042 & 1 & \\
\hline $14 \mathrm{CPI}$ & -0.020 & 0.036 & 0.009 & -0.077 & 0.033 & -0.026 & -0.057 & 0.034 & -0.057 & 0.079 & 0.020 & 0.015 & $0.564 * * *$ & 1 \\
\hline
\end{tabular}

Notes: $*, * *$ and $* * *$ indicates significance at the $10 \%, 5 \%$ and $1 \%$ level, respectively.

Source: Author's own calculation

\subsection{Regression results}

Regression results are shown in Table 6, Table 7, and Table 8. The explanatory power of Models (1)-(3) is 22.5 percent, 32.7 percent, and 29.0 percent, respectively. When ROS is used as the dependent variable, long-term liability ratio (LONG) has a positive impact while debt ratio (LEV) and capital intensity (CAP) have a negative impact. Other variables have no significant impact on ROS. Bayaraa (2017) also argued that long-term debt to assets ratio, which has a positive impact, is a determinant for ROS in Mongolia's agricultural sector. In addition, it seems that excess debt increases financial distress cost of an organization and decreases financial performance.

The insignificant coefficients of GDP and CPI point out that macroeconomic environment does not improve financial positions of agricultural listed companies, contrary to Gan et al. (2006), Kosmidou (2008), Antoun et al. (2018), and Vieira et al. (2019).

Table 6: Regression results of Model (1)

\begin{tabular}{|c|c|c|c|c|c|c|}
\hline \multirow{2}{*}{\multicolumn{2}{|c|}{ Model }} & \multicolumn{2}{|c|}{ Unstandardized Coefficients } & \multirow{2}{*}{$\begin{array}{c}\text { Standardized Coefficients } \\
\beta\end{array}$} & \multirow[t]{2}{*}{$\mathrm{T}$} & \multirow[t]{2}{*}{ Sig. } \\
\hline & & $\mathrm{B}$ & Std. Error & & & \\
\hline \multirow[t]{12}{*}{1} & Constant & -3.126 & 2.762 & & -1.132 & 0.259 \\
\hline & SIZE & 0.139 & 0.092 & 0.103 & 1.500 & 0.135 \\
\hline & CR & 0.020 & 0.029 & 0.056 & 0.672 & 0.503 \\
\hline & LEV & -2.123 & 0.549 & -0.315 & -3.864 & 0.000 \\
\hline & LONG & 6.056 & 1.202 & 0.374 & 5.039 & 0.000 \\
\hline & SALES & 0.062 & 0.219 & 0.018 & 0.282 & 0.778 \\
\hline & CAP & -0.302 & 0.049 & -0.475 & -6.205 & 0.000 \\
\hline & $\mathrm{RD}$ & 1.442 & 1.634 & 0.056 & 0.882 & 0.379 \\
\hline & EXP & -0.606 & 0.427 & -0.090 & -1.418 & 0.158 \\
\hline & OWN & 0.114 & 0.161 & 0.045 & 0.705 & 0.482 \\
\hline & GDP & 28.899 & 24.005 & 0.091 & 1.204 & 0.230 \\
\hline & CPI & -28.233 & 24.991 & -0.083 & -1.130 & 0.260 \\
\hline \multicolumn{4}{|c|}{$\mathrm{R}^{2}=0.265$} & \multicolumn{3}{|c|}{ Adj. $R^{2}=0.225$} \\
\hline \multicolumn{4}{|c|}{$\mathrm{F}=6.628 * * *$} & \multicolumn{3}{|l|}{$\mathrm{N}=214$} \\
\hline
\end{tabular}

www.custoseagronegocioonline.com.br 
Notes: *** indicates significance at the $1 \%$ level.

Source: Author's own calculation

In Model (2), SIZE, LONG, and SALES positively affect ROA, whereas LEV, CAP, and EXP have a negative impact. In addition, CR, RD, OWN, GDP, and CPI do not show statistically significant impact on ROA.ROA has more determinants than ROS and ROE.

The positive impact of SIZE means that when agricultural listed companies become larger, their ability to generate returns gradually improves. However, Jelena et al. (2018) and Dakić et al. (2019) found that firm size has a negative influence on ROA. Meiryani et al. (2020) argued that firm size has no impact on financial performance measured through ROA in Indonesia's manufacturing sector.

CR has a positive but insignificant impact on ROA, inconsistent with Jelena et al. (2018). The coefficient of LEV is negative and significant $(\beta=-0.392, t=-6.383)$. Using data from Brazilian agribusiness, Hall et al. (2014) found that they have greater impact on the cost of debt to capital structure as well as higher returns. Long-term debt can positively impact financial performance, which signifies the relative strength of agricultural listed comapnies. The positive coefficient of SALES suggests that agricultural listed companies grow healthily. CAP negatively affects ROA, which is not in line with Harris (1988) who found a positive relationship between capital intensity and firm performance.

RD has a positive but insignificant impact on ROA. However, Wei and Huang (2015) concluded that agricultural listed companies accelerate business performance through the investment in R\&D. Wang (2019) also pointed out that the current $R \& D$ investment stimulates financial performance of agricultural listed companies.

An and Kim (2019) confirmed a negative but insignificant relationship between ratio of export and financial performance of auto parts cooperative companies. However, the export of agricultural product can provide revenue collection in higher amount (Jelena et al., 2018). For agriculture sector in Serbia, export significantly affects firm profitability (Jelena et al., 2018). Munch and Schaur (2018) argued that export promotion increases sales and value added of Danish firms. Yildiz (2018) confirmed a positive relationship between export intensity and firm performance of listed firm in Borsa Istanbul.

In Mongolian agricultural sector, the impact of earnings per share and return on costs is reflected in the ROA (Bayaraa, 2017). Mijić and Jakšić (2017) concluded that profitability of agricultural firms is positively related to leverage, quick ratio, sales growth rate, and lagged profitability in Hungary and Romania. What's more, size and fixed assets ratio negatively affect firm profitability. In another three countries (i.e. Serbia, Bosnia, and Herzegovina), 
quick ratio, growth, and lagged profitability positively influence ROA.

Table 7: Regression results of Model (2)

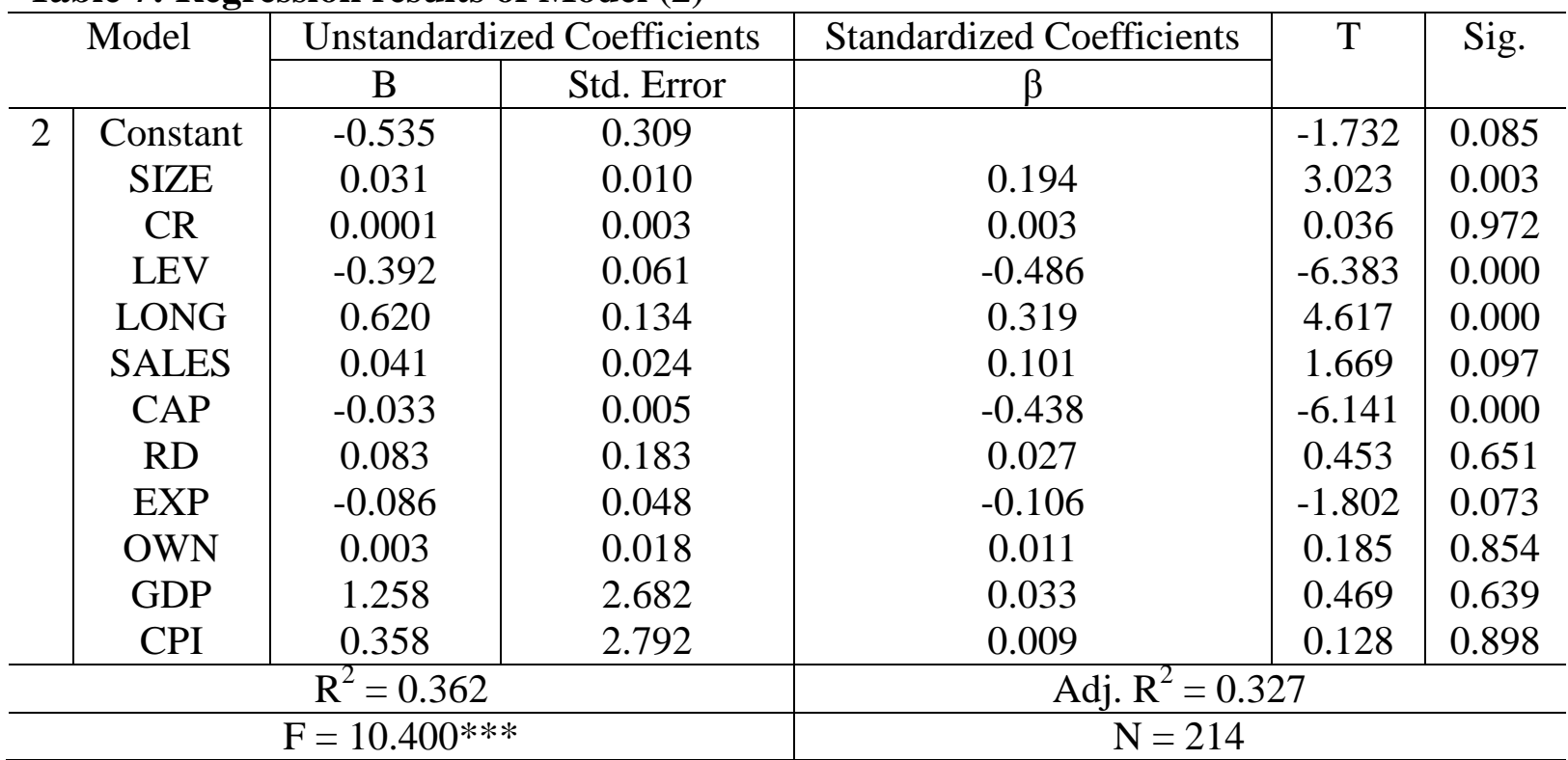

Notes: $* * *$ indicates significance at the $1 \%$ level.

Source: Author's own calculation

In terms of ROE, the coefficients of SIZE and LONG are positive and significant $(\beta=$ $0.071, t=2.018 ; \beta=2.102, t=4.593)$. LEV and CAP exert a significantly negative impact on $\operatorname{ROE}(\beta=-1.159, t=-5.540 ; \beta=-0.117, t=-6.313)$. The coefficient of $\mathrm{RD}$ is positive but not significant at the $5 \%$ level $(\beta=0.503, t=0.808)$, and the coefficient of EXP is negative but not significant at the $5 \%$ level $(\beta=-0.269, t=-1.651)$.

Table 8: Regression results of Model (3)

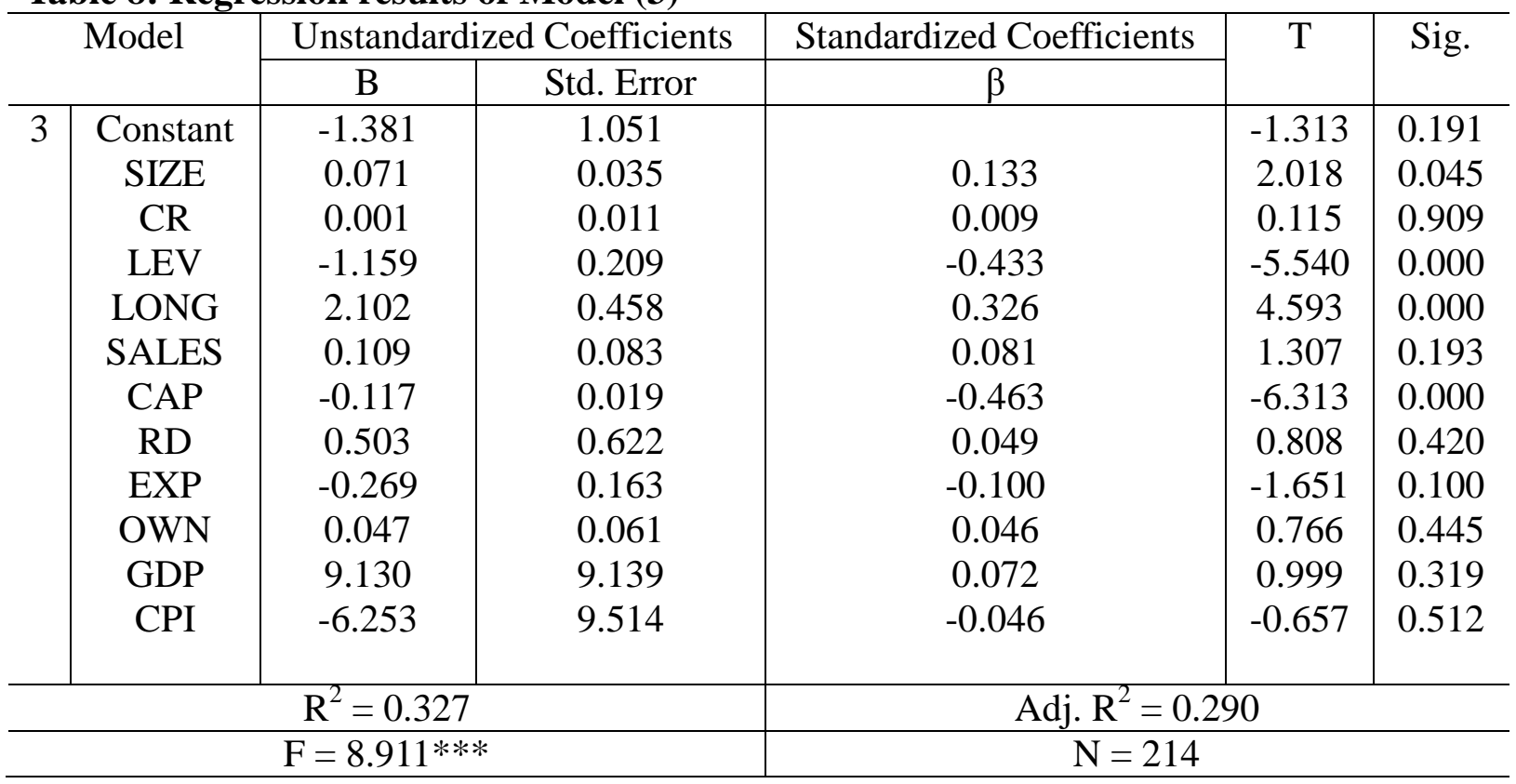

Custos e @gronegócio on line - v. 16, n. 4, Oct/Dec. - 2020. 
Notes: *** indicates significance at the $1 \%$ level.

Source: Author's own calculation

\subsection{Robustness check}

We also use the ratio of earnings before interest and taxes to average total assets as an alternative measure of ROA to re-estimate Model (2). The results are similar to the findings in Table 7, suggesting that our conclusion is robust.

\section{Conclusions}

The study shows that determining factors influence financial performance of agricultural listed companies in China. By using data retrieved from 39 agricultural listed companies during 2013-2018, the conclusions can be summarized in three aspects. First, financial performance of China's agricultural listed companies has a fluctuating downward trend. Second, firm size, long-term liability ratio, and sales growth rate can improve financial performance. Third, debt ratio, capital intensity, and export intensity hinders financial performance.

The findings of this study offer several practical implications. First, agricultural listed companies should not pursue more profits by blindly expanding company size. Managers should consider whether size structure is compatible with the requirements of production level. Second, the insignificant impact of CR indicates that agricultural listed companies should take into account the optimal level of liquidity because excess cash flow that is not invested cannot contribute to performance improvement. Third, corporate managers should pay attention to capital structure and reasonably utilize long-term borrowings to maintain financial sustainability. Fourth, agricultural listed companies should pay attention to the relationship between sales revenue and cost of sales where an increase in sales growth can be achieved by enhancing product volume or sales price. Fifth, agricultural listed companies should increase investment in R\&D and introduce advanced machinery and equipment in order to raise the level of modernization. Sixth, these companies should change their production structure for export and develop high-tech agricultural products through the utilization of advanced technology. Finally, for investor, they should take into account various factors to systematically assess a firm when making investment decisions.

There are some limitations in this study. First, we only focus on agricultural industry and other industries should be included. Second, other factors (e.g. board diversity, public 
support, and unemployment rate) influencing financial performance should also be taken into account in this study. These limitations signal the scope for future research.

\section{References}

AN, H.-J.; KIM, W.K. A case study on the influence factors of financial performance of Korean automotive parts cooperation companies through research hypothesis. The Journal of Asian Finance, Economics and Business, v. 6, n. 3, p. 327-337, 2019.

ANTOUN, R.; COSKUN, A.; GEORGIEVSKI, B. Determinants of financial performance of banks in Central and Eastern Europe. Business and Economic Horizons, v. 14, n. 3, p. 513$529,2018$.

ARISOY, H.; BAYRAMOGLU, Z.; KARAKAYACI, Z.; OGUZ, C. The effect of agricultural support on the economic sustainability of agricultural enterprises. Custos e Agronegocio On Line, v. 13, n. 3, p. 233-253, 2017.

AVDALOVIĆ, S.M. Impact of firm specific factors on profitability of industrial grinding companies. Economics of Agriculture, v. 65, n. 2, p. 493-501, 2018.

AZHAGAIAH, R.; DEEPA, R. Determinants of profitability of food industry in India: A sizewise analysis. Management, v. 7, n. 2, p. 111-128, 2012.

BAYARAA, B. Financial performance determinants of organizations: The case of Mongolian companies. Journal of Competitiveness, v. 9, n. 3, p. 22-33, 2017.

BUGU, Z.Y.; YUCHENG, H. An empirical analysis of the factors affecting the profitability of China's agricultural listed companies under the background of agricultural modernization. International Journal of Applied Economics, Finance and Accounting, v. 2, n. 1, p. 19-26, 2018.

CHANDRAPALA, P., GUNERATNE, W. Ownership concentration and financial performance: the case of Sri Lankan listed companies. Corporate Ownership and Control, v. 9, n. 4, p. 170-177, 2012. 
CHEN, T.-C.; WU, Y.J. The influence of R\&D intensity on financial performance: The mediating role of human capital in the semiconductor industry in Taiwan. Sustainability, v. 12, n. 12 , p. $5128,2020$.

CHHIBBER, P.K.; MAJUMDER, K.K. Foreign ownership and profitability: Property rights, control, and the performance of firms in Indian industry. Journal of Law and Economics, v. 42, n. 1, p. 209-238, 1999.

CHOWDHURY, A.; AMIN, M.M. Working capital management practiced in pharmaceutical companies listed in Dhaka stock exchange. BRAC University Journal, v. 4, n. 2, p. 75-86, 2007.

DAKIĆ, S.; MIJIĆ, K.; JAKŠIĆ, D. Multiple regression approach to modelling determinants of business success based on financial statement: Evidence from food processing companies in the Republic of Serbia. Custos e Agronegocio On Line, v. 15, n. 4, p. 485-501, 2019.

FALK, M. Quantile estimates of the impact of R\&D intensity on firm performance. Small Business Economics, v. 39, n. 1, p. 19-37, 2012.

FIALA, R.; HEDIJA, V.; DVORAK, J.; JANSKY, J. Are profitable firms also financially healthy? Empirical evidence for pig-breeding sector. Custos e Agronegocio On Line, v. 16, n. 1, p. 173-201, 2020.

GAN, C.; LEE, M.; YONG, H.H.A.; ZHANG, J. Macroeconomic variables and stock market interactions: New Zealand evidence. Investment Management and Financial Innovation, v. 3, n. 4, p. 80-101, 2006.

GAO, K.; SHAO, X.-X. Fundamental problems, causes and focuses of China's agricultural supply-side structural reform. Journal of Interdisciplinary Mathematics, v. 21, n. 5, p. 13751379, 2018.

GSCHWANDTNER, A. Profit persistence in the 'very' long run: evidence from survivors and exiters. Applied Economics, v. 37, n. 7, p. 793-806, 2005. 
HALL, R.J.; KAVESKI, I.D.S.; HEIN, N. Analysis of the debt and impact on cost of debt and profitability of companies listed on Brazilian agribusiness BM\&FBoyespa. Custos $e$ Agronegocio On Line, v. 10, n. 4, p. 39-59, 2014.

HARRIS, F.H.D. Capital intensity and the firm's cost of capital. The Review of Economics and Statistics, v. 70, n. 4, p. 587-594, 1988.

HARRIS, F.H.D. Asset specificity, capital intensity and capital structure: An empirical test. Managerial and Decision Economics, v. 15, n. 6, p. 563-576, 1994.

HULT, G.T.M.; KETCHEN, D.J.; GRIFFITH, D.A.; CHABOWSKI, B. R.; HAMMAN, M.K.; DYKES, B.J.; POLLITTE, W.A.; CAVUSGIL, S.T. An assessment of the measurement of performance in international business research. Journal of International Business Studies, v. 39, n. 6, p. 1064-1080, 2008.

HUO, Y.L. Problems research on agricultural listed companies in China's securities market. 2016.

(available at: https://download.atlantis-press.com/article/25865279.pdf)

JELENA, A.; KRISTINA, M.; VERA, M.; BRANIMIR, K. The modelling factors of agricultural companies performances. Custos e Agronegocio On Line, v. 14, n. 4, p. 223-240, 2018.

JIN, Z.J.; SHANG, Y.; XU, J. The impact of government subsidies on private R\&D and firm performance: Does ownership matter in China's manufacturing industry? Sustainability, v. 10, n. 7, p. 2205, 2018.

KENNEDY, P. A Guide to Econometrics. MIT Press, Cambridge, 2003.

KOSMIDOU, K. The determinants of banks' profits in Greece during the period of EU financial integration. Management Finance, v. 34, n. 3, p. 146-159, 2008.

KUMARI, R.; KUMAR, N. Determinants of firm performance: A conceptual analysis. Pacific 
Business Review International, v. 10, n. 11, p. 133-140, 2018.

KUNTLURU, S.; MUPPANI, V.R.; KHAN, A.M. Financial performance of foreign and domestic owned companies in India. Journal of Asia-Pacific Business, v. 9, n. 1, p. 28-54, 2008.

LI, X.G.; ZHANG, Y.Q.; LIANG, L.P. Measure of agricultural production input/output efficiency and the spatial display analysis in China. Custos e Agronegocio On Line, v. 13, n. 2, p. 408-420, 2017.

LUO, H.-W.; ZHANG, W. Performance evaluation of China's agricultural listed companies based on DEA model. Asian Agricultural Research, v. 4, n. 5, p. 1-6, 2012.

MEIRYANI; OLIVIA; SUDRAJAT, J.; DAUD, Z.M. The effect of firm's size on corporate performance. International Journal of Advanced Computer Science and Applications, v. 11, n. 5, p. 272-277, 2020.

MIJIĆ, K.; JAKŠIĆ, D. The determinants of agricultural industry profitability: evidence from southeast Europe. Custos e Agronegocio On Line, v. 13, n. 1, p. 154-173, 2017.

MIJIĆ, K.; ZEKIĆ, S.; JAKŠIĆ, D.; VUKOVIĆ, B. Meat industry in Serbia: performance analysis of meat-processing and livestock companies. Custos e Agronegocio On Line, v. 10, n. 3, p. 124-144, 2014.

MUNCH, J.; SCHAUR, G. The effect of export promotion on firm-level performance. American Economic Journal-Economic Policy, v. 10, n. 1, p. 357-387, 2018.

PATHIRAWASAM, C. Internal factors which determine financial performance of firms: with special reference to ownership concentration. 2011.

(available at: https://www.slu.cz/opf/cz/informace/acta-academica-karviniensia/casopisyaak/aak-rocnik-2013/docs-2-2013/Pathirawasam.pdf/)

PRATHEEPAN, T. A panel data analysis of profitability determinants: Empirical results from Sri Lankan manufacturing companies. International Journal of Economics, Commerce and 
Management, v. 2, n. 12, p. 1-9, 2014.

SINGH, K.; MISRA, M.; KUMAR, M.; TIWARI, V. A study on the determinants of financial performance of US agricultural cooperatives. Journal of Business Economics and Management, v. 20, n. 4, p. 633-647, 2019.

SOPHIA, S.F; GAYATHRI, J. Firm size and performance with special reference to multinational pharmaceutical firms. Pacific Business Review International, v. 10, n. 8, p. 33 38, 2018.

STIERWALD, A. Determinants of profitability: An analysis of large Australian firms. 2010. (available at: https://melbourneinstitute.unimelb.edu.au/downloads/working_paper_series/wp2010n03.pdf)

VIEIRA, E.S.; NEVES, M.E.; DIAS, A.G. Determinants of Portuguese firms' financial performance: panel data evidence. International Journal of Productivity and Performance Management, v. 68, n. 7, p. 1323-1342, 2019.

VU, T.-H.; NGUYEN, V.-D.; HO, M.-T.; VUONG, Q.-H. Determinants of Vietnamese listed firm performance: Competition, wage, CEO, firm size, age, and international trade. Journal of Risk and Financial Management, v. 12, n. 2, p. 62, 2019.

WAGAN, S.A.; MEMON, Q.U.; DONG, C.Y.; LUAN, J.D. A comparative study on agricultural production efficiency between China and Pakistan using Data Envelopment Analysis (DEA). Custos e Agronegocio On Line, v. 14, n. 3, p. 169-190, 2018.

WANG, P. Research on the impact of R\&D investment on financial performance of agricultural listed companies. Journal of Inner Mongolia University of Finance and Economics, v. 17, n. 2, p. 43-46, 2019.

WEI, C.-S.; HUANG, X.-J. Study on influence of research and development investment on business performance of agricultural listed companies based on DEA model. Acta Agricultural Jiangxi, v. 27, n. 11, p. 129-133, 2015. 
WEI, F.; LU, J.W.; KONG, Y. Research on sustainability financial performance of Chinese listed companies. Sustainability, v. 9, n. 5, p. 723, 2017.

WEI, W.; TANG, J.M. Ownership transformation, firm performance and manufacturing growth in China. Economics of Transition, v. 27, n. 2, p. 475-496, 2019.

XU, J.; SIM, J.-W. Characteristics of corporate R\&D investment in emerging markets: Evidence from manufacturing industry in China and South Korea. Sustainability, v. 10, n. 9, p. $3002,2018$.

XU, J.; WANG, B.H. Intellectual capital and financial performance of Chinese agricultural listed companies. Custos e Agronegocio On Line, v. 15, n. 1, p. 273-290, 2019.

XUAN, V.N. Determinants of business performance in firms: Evidence in Vietnam technology and manufacturing enterprises. International Journal of Advanced and Applied Science, v. 7, n. 7, p. 95-101, 2020.

YILDIZ, Y. Export intensity, R\&D investments, and firm performance: Evidence from Turkey. Ege Academic Review, v. 18, n. 2, p. 307-319, 2018.

ZHU, G.-L.; ZHANG, Y.; CHEN, K.-H.; YU, J. The impact of R\&D intensity on firm performance in an emerging market: Evidence from China's electronics manufacturing firms. Asian Journal of Technology Innovation, v. 25, n. 1, p. 41-60, 2017.

\section{Acknowledgements}

This research was financially supported by the Qingdao Zexu Network Technology Co., Ltd (Grant Number ZX2020-02). 